\title{
Proposed classification for the lip lesions (Dr. Patil's classification)
}

Sir,

Lips are placed in a very prominent position and play an important role in the manipulation of food and phonetics, and are affected by various disorders. These disorders may be simple without significant functional morbidity or may be complex and alarming. Lips known to be more susceptible to damage from the elements, the environment, trauma, and infection. Diagnosis and treatment of lip abnormalities are important, not only to prevent disease morbidity and mortality, but also to restore social acceptance and self-esteem. Most of the lip disorders may present with the common characteristics and may be indistinguishable clinically. Angular cheilitis, usually seen bilaterally at the corner of the mouth is a reactive process with variable etiological possibilities such as infections, mechanical, nutritional deficiency, and dermatoses. Contact cheilitis may be seen because of a primary irritant or a delayed hypersensitivity reactions. Exfoliative cheilitis is a reactive condition secondary to the factitious activity of the patient. Cheilitis glandularis is a chronic inflammatory disorder which affects the labial salivary glands and their ducts. Cheilitis granulomatosa may be seen as one manifestation of orofacial granulomatosis. The granulomatous conditions of Melkersson-Rosenthal syndrome, sarcoidosis, and Crohn's disease may be associated with cheilitis granulomatosa, or it may stand alone as Miescher's cheilitis. ${ }^{[-3]} \mathrm{A}$ cleft lip may be seen due to developmental defects. ${ }^{[4]}$ Apart from these conditions various malignant and premalignant conditions such as

\begin{tabular}{ll}
\multicolumn{2}{l}{ Table 1: Proposed classifi cation for the lip lesions } \\
\hline Etiology & Type of Disorders \\
\hline Developmental & $\begin{array}{l}\text { Cleft lip, fordyce spots, double lip, congenital } \\
\text { lip and commissural pits and fistulas, } \\
\text { macrocheilia, microcheilia, eclabium } \\
\text { Viral: Herpes simplex/rcurrent herpes labialis } \\
\text { Bacterial: Staphylococcus aureus (impetigo) }\end{array}$ \\
$\begin{array}{ll}\text { Infection } & \text { Fungal: Candida albicans (angular cheilits) } \\
\text { Granulomatous } & \text { Sarcoidosis, crohns disease, tuberculosis, } \\
\text { disorders } & \text { cystic fibrosis } \\
\text { Autoimmune } & \text { SLE, erythema multiforme } \\
\text { disorders } & \text { Cheilitis glandularis, cheilitis granulomatosa, } \\
\text { Inflammatory } & \text { exfoliative cheilitis, contact cheilitis, chronic } \\
\text { conditions } & \text { atrophic-abrasive cheilitis, eczema around lips } \\
\text { Allergic } & \text { Angioneurotic edema } \\
\text { Obstructive salivary } & \text { Mucocele } \\
\text { gland disorder } & \\
\text { Pigmented lesions } & \text { Hemangioma, lentigo, labial melanotic macule } \\
\text { Premalignant lesions } \\
\text { and conditions }\end{array}$ & $\begin{array}{l}\text { Leukoplakia, OSMF, actinic cheilitis, } \\
\text { Intradermal naevus, lichenplanus }\end{array}$ \\
$\begin{array}{l}\text { Benign neoplasias } \\
\text { Malignancies }\end{array}$ & $\begin{array}{l}\text { Fibroma, papilloma } \\
\text { Squamous cell carcinoma, basal cell } \\
\text { carcinoma }\end{array}$ \\
\hline
\end{tabular}

SLE = Systemic lupus erythematosus, OSMF = Oral submucous fibrosis squamous cell carcinoma, basal cell carcinoma, leukoplakia, oral submucous fibrosis, and actinic cheilitis are seen to be affecting the lips. ${ }^{[5]}$ The problem of classification of lip diseases is extremely difficult and complex. When literature is analyzed, it can be seen that no much attempts have been made to classify lip diseases. Consequently, we are proposing a simple classification for lip diseases which may be universally accepted [Table 1].

\section{Financial support and sponsorship}

Nil.

\section{Conflicts of interest}

There are no conflicts of interest.

\section{Santosh Patil}

Department of Oral Medicine and Radiology, College of Dentistry, AlJouf University, Skaka, Aljouf, Kingdom of Saudi Arabia

\section{Address for the Correspondence:}

Dr. Santosh Patil,

Department of Oral Medicine and Radiology, College of Dentistry, Aljouf University, Skaka, Aljouf, Kingdom of Saudi Arabia.

E-mail: drpsantosh@gmail.com

\section{REFERENCES}

1. Williams AJ, Wray D, Ferguson A. The clinical entity of orofacial Crohn's disease. Q J Med 1991;79:451-8.

2. Blinder D, Yahatom R, Taicher S. Oral manifestations of sarcoidosis. Oral Surg Oral Med Oral Pathol Oral Radiol Endod 1997;83:458-61.

3. Sutton RL. The symptomatology and treatment of three common diseases of the vermilion border of the lip. Int Clin (Series 24) 1914;3:123-8.

4. McLeod NM, Urioste ML, Saeed NR. Birth prevalence of cleft lip and palate in Sucre, Bolivia. Cleft Palate Craniofac J 2004;41:195-8.

5. Neville BW, Day TA. Oral cancer and precancerous lesions. CA Cancer J Clin 2002;52:195-215.

This is an open access article distributed under the terms of the Creative Commons Attribution-NonCommercial-ShareAlike 3.0 License, which allows others to remix, tweak, and build upon the work non-commercially, as long as the author is credited and the new creations are licensed under the identical terms.

\begin{tabular}{|l|l|}
\hline Access this article online & \\
\hline Quick Response Code: & Website: \\
\hline & www.jimedph.org \\
\hline & \\
\hline
\end{tabular}

How to cite this article: Patil S. Proposed classification for the lip lesions (Dr. Patil's classification). Int J Med Public Health 2016;6:56. 